\title{
Karakter Dan Pola Tata Ruang Kawasan Sekitar Kampus Universitas Brawijya
}

\author{
Subhan Ramdlani ${ }^{1}$, Ali Soekirno ${ }^{2}$, dan Novi Sunu Sri Giriwati ${ }^{3}$ \\ ${ }^{1}$ Jurusan Arsitektur/Fakultas Teknik, Universitas Brawijaya \\ ${ }^{2}$ Jurusan Arsitektur/Fakultas Teknik, Universitas Brawijaya \\ 3 Jurusan Arsitektur/Universitas Brawijaya \\ AlamatEmail: sramdlani@gmail.com, ramdlani94@ub.ac.id
}

\begin{abstract}
Abstrak
Kawasan sekitar kampus Universitas Brawijaya merupakan kawasan yang terdampak oleh perkembangan Universitas Brawijaya. Perkembangan tata ruang kampus Universitas Brawijaya (UB) ikut mempengaruhi perkembangan tata ruang kawasan sekitar kampus. Sebaliknya apa yang terjadi dalam kawasan pendukung ini, menjadi masukan penting dalam perkembangan kampus UB mendatang. Tujuan penelitian ini adalah untuk mengidentifikasi karakteristik dan tata ruang kawasan sekitar kampus UB serta menemukenali pola pemanfaatan ruang sesuai karakternya masing-masing. Dengan mempelajari dan memahami kondisi yang ada, hasil penelitian diharapkan dapat digunakan sebagai salah satu "database" atau bahkan "input" dalam menetapkan arahan pengembangan kampus UB, baik di lokasi saat ini (kelurahan Ketawang Gedhe) maupun sebagai "preseden" dalam pengembangan kampus UB di lokasi lain. Sehingga akan tercipta lingkungan yang harmonis dan saling mendukung antara kampus UB dan kawasan sekitarnya. Penelitian ini menggunakan metode deskriptif kualitatif. Pengamatan dan kajian dilakukan terhadap spot-spot pola pemanfaatan lahan pada kawasan sekitar kampus, berupa blok hunian, ruang terbuka, sarana prasarana lain yang tersebar di beberapa kawasan sekitar kampus UB. Dengan demikian, akan didapatkan karakteristik (struktur, bentuk dan ruang) kawasan dan pola tata ruang kawasan yang menjadi bahan kajian untuk menjelaskan keterkaitan kawasan dengan perkembangan tata ruang kampus.
\end{abstract}

Kata kunci: karakter, tata ruang, kampus

\begin{abstract}
The Surrounding of UB campus are an area affected directly or indirectly by the development of UB. The developments of the campus will be more or less influence to the spatial development of this area. Conversely, the dynamics that occur in this area will be an important input in the development of the upcoming campus. From this point, the purpose of this study was to identify the characteristics and spatial surrounding area of UB campus as patterns of land use that fit by the character. By studying and understanding the existing conditions, the results are expected to be used as one of the "database" or even "input" in determining the direction of development of the UB campus. That will create a harmonious environment and mutual support between the UB campus and the surrounding. To achieve these objectives, this study used a qualitative descriptive method. Observations and studies carried out on spot-spot patterns of land use in the area surrounding the campus, a block of residential, open space, other infrastructure spread over several areas around campus UB (UB). Thus, gain characteristics (structure, shape and space) and the spatial pattern of the area of study materials to explain the link with the development of the UB campus layout.
\end{abstract}

Keywords: character, layout, campus. 


\section{Pendahuluan}

Perkembangan sebuah kawasan tidak akan pernah terlepas dari perkembangan kawasan di sekitarnya. Jika sebuah kawasan berkembang pesat, maka secara perlahan hal ini akan mendorong perkembangan kawasan pendukungnya. Bukan hanya menjadi "generator" kawasan sekitarnya, perkembangan yang terjadi pada kawasan inti bahkan turut mempengaruhi karakter dan pola pemanfaatan ruang di sekitarnya.

Keberadaan sebuah lembaga pendidikan yang cukup besar merupakan salah satu alasan terjadinya proses urbanisasi pada suatu wilayah. Peningkatan jumlah populasi sebagai akibat langsung proses urbanisasi menjadi peluang pasar baru bagi kegiatan ekonomi masyarakat seiring dengan meningkatnya jumlah permintaan barang-barang kebutuhan. Selain hal tersebut terkonsentrasinya populasi pada satu titik lokasi tentunya juga akan membawa dampak bagi pola tata ruang di wilayah tersebut. Dalam hal ini pola tata ruang merupakan penampakan fisik ruang yang terjadi sebagai akibat terjadinya aktivitas kegiatan pada suatu wilayah.

Menurut Richardson (1972) proses pembangunan ekonomi dengan adanya kecenderungan pemusatan penduduk dan ketersediaan fasilitas, maka investasi di wilayah inti pada mulanya lebih efisien karena berkaitan dengan efisiensi usaha (economies of scale) di mana masing - masing individu akan memanfaatkan keuntungan-keuntungan eksternal. Pelaksanaan suatu usaha atau program pembangunan ekonomi tidak hanya memberikan dampak positif terhadap keadaan ekonomi pelaksana usaha tersebut, tetapi juga memberikan dampak positif terhadap perekonomian wilayah dan masyarakat secara keseluruhan. Adanya kegiatan atau program pembangunan ekonomi dalam suatu lingkup perekonomian yang semakin berkembang akan menciptakan keterkaitan yang semakin kuat dan dinamis di antara berbagai sektor ekonomi.

Kampus Universitas Brawijaya (UB) memiliki kawasan pendukung di sekitarnya. Keberadaan kawasan pendukung ini memiliki peran penting bagi berjalannya kehidupan kampus. Hampir semua kebutuhan penghuni kampus dapat terpenuhi di dalamnya. Jumlah mahasiswa yang terus meningkat setiap tahunnya, dapat terserap dengan baik di kawasan ini. Hasilnya, kepadatan penduduk (density) kawasan ini terus meningkat. Dan yang terjadi adalah pertumbuhan kawasan yang tidak terkendalikan (urban sprawl). Lokasi yang berdekatan dengan kampus menjadi sasaran mahasiswa dalam memilih lokasi hunian.

Pertumbuhan jumlah mahasiswa di kawasan ini, secara perlahan mendapat tanggapan dari lingkungan kawasan tersebut. Kebutuhan sehari-hari para mahasiswa mulai dari akomodasi dan konsumsi, tersedia dalam berbagai level harga yang terjangkau. Masyarakat setempat menyisihkan ruang di lingkungan mereka untuk menampung fungsi pelayanan ini. Meningkatnya fungsi pelayanan publik ini sedikit banyak berpengaruh pada pola pemanfaatan ruang kawasan. Hal inilah yang dianggap sebagai implikasi dari pertumbuhan kota/kawasan yang cepat secara langsung, khususnya pada pembangunan infrastruktur dasar dan pelayanan publiknya (Nurmandi, 1999).

Perkembangan kampus UB secara tidak langsung membuat lingkungan sekitar kampus juga ikut berkembang. Hal tersebut terlihat pada makin banyaknya rumah warga yang mengalami perkembangan fisik untuk menampung fungsi baru baik secara vertikal maupun horisontal. Pertumbuhannya semakin cepat hingga di beberapa titik kawasan terlihat padat. Perkembangan permukiman di kawasan sekitar kampus UB kebanyakan dengan kondisi yang relatif kurang baik karena banyaknya pendirian rumah oleh 
masyarakat yang kurang disertai penataan. Kawasan permukiman tersebut terutama terdapat di wilayah kelurahan Ketawang Gedhe, Penanggungan, dan Dinoyo. Kondisi lingkungan permukiman tersebut semakin merosot seiring dengan terus meningkatnya jumlah penduduk. Daya dukung lingkungan semakin menurun. Akibatnya, rumah warga semakin berhimpitan, jalan tidak mencukupi kebutuhan, serta ruang terbuka publik makin berkurang, bahkan terkesan kumuh. Jalan lingkungan menjadi lebih padat karena dilalui pengendara yang melintasi kawasan. Kebisingan dan kesemrawutan tidak dapat dielakkan.

Kepadatan jumlah penduduk pada akhirnya juga disertai makin beragamnya pemanfaatan lahan oleh masyarakat. Beragam jenis usaha melengkapi fungsi hunian mereka menjadi fungsi yang lebih kompleks. Perubahan fungsi lahan juga terjadi di kawasan sekitar kampus yang bersentuhan langsung dengan aktifitas mahasiswa. Kawasan permukiman sedikit demi sedkit menjadi kawasan perdagangan jasa. Perubahan fungsi lahan ini memaksa masyarakat asli pindah atau bertahan di bagian dalam kawasan. Bahkan untuk kawasan sepanjang DAS Brantas, banyak penduduk asli maupun pendatang yang mencoba bertahan dengan membangun rumahnya berada pada kawasan yang rawan bencana (banjir dan longsor) dan melanggar garis sempadan sungai (daerah bantaran atau stren sungai) yang seharusnya tertutup bagi kegiatan budidaya.

Perkembangan kawasan sekitar kampus yang sedemikian cepat tentu tidak dapat dipandang remeh atau sepele. Keberadaan kampus di tengah-tengah masyarakat seharusnya merupakan hubungan mutualisme yang tidak merugikan salah satu pihak. Setiap kebijakan tata ruang yang muncul di kampus, maka akan turut dirasakan oleh masyarakat sekitar kampus. Sebagai sebuah contoh, perubahan arus sirkulasi kendaraan keluar dan masuk kampus, secara tidak langsung akan direspon dan dirasakan langsung oleh masyarakat sekitar kampus. Untuk itulah perlu diketahui lebih awal karakter dan pola tata ruang kawasan sekitar kampus sebagai bentuk hubungan spasial yang tak terpisahkan dengan keberadaan kampus. Mengidentifikasi adalah sebuah langkah awal sebelum dilakukan tindakan lebih lanjut untuk mengantisipasi perkembangan tata ruang kampus. Obyek dan elemen yang diamati dalam proses identifikasi antara lain, tipe-tipe bentukan, ruang-ruang terbuka/ bersama, sirkulasi, jalur hijau, beserta pola pemanfaatan ruangnya yang berada di kawasan sekitar kampus Universitas Brawijaya.

\section{Bahan dan Metode}

\subsection{Tinjauan Pustaka}

Dalam kerangka tata ruang kota, pengembangan suatu bagian wilayah kota akan berpengaruh pada pengembangan kawasan sekitarnya, sesuai fungsi yang diemban kawasan tersebut.

\subsubsection{Kampus sebagai Infrastruktur Kota}

Dalam konteks tata ruang kawasan, kampus dapat dipandang sebagai sebuah sarana dan prasarana atau infrastruktur kota. Grigg mendefinisikan prasarana dan sarana atau infrastruktur sebagai fasilitas fisik suatu kota atau negara yang sering disebut prasarana umum (Suripin, 2004). Secara umum dapat disimpulkan bahwa infrastruktur perkotaan yang di dalamnya termasuk sarana dan prasarana pendidikan merupakan bangunan atau fasilitas-fasilitas dasar, peralatan-peralatan, dan instalasi-instalasi yang dibangun dan dibutuhkan untuk mendukung berfungsinya suatu sistem tatanan kehidupan sosial ekonomi masyarakat. Infrastruktur merupakan aset fisik yang dirancang dalam sistem, 
sehingga mampu memberikan pelayanan prima kepada masyarakat. Sebagai sebuah sistem yang terdiri dari banyak komponen, maka perencanaan infrastruktur harus mempertimbangkan keterkaitan dan keterpengaruhan antar komponen, beserta dampakdampaknya.

Perencanaan infrastruktur merupakan proses dengan kompleksitas tinggi, multi disiplin, multi sektor, dan multi pengguna (user). Oleh karena itu perencanaan infrastruktur tidak bisa sektoral, namun juga tidak bisa terlalu global. Jika perencanaan terlalu spesifik (bersifat sektoral) tanpa mempedulikan komponen lain, maka akan banyak bertabrakan dengan komponen lainnya. Sebaliknya menurut Grigg (Suripin, 2004), jika terlalu global, hasilnya tidak akan efektif. Perencanaan yang (mungkin) paling baik adalah yang berada diantaranya, yaitu perencanaan yang didasarkan pada pendekatan permasalahan secara global pada tingkatan yang tepat dengan mempertimbangkan secara matang segala dampak eksternalnya, namun masih berkonsentrasi secara spesifik pada persoalan utama yang ingin dipecahkan. Dalam pengertian diatas perencanaan sarana dan prasana pendidikan sebaiknya tidak berfokus pada sektor pendidikannya saja, tetapi juga harus juga mempertimbangkan sektor sosial-ekonomi masyarakat yang terkait dengannya.

Fungsi pendidikan, bahkan pendidikan tinggi, sesungguhnya hadir untuk memenuhi kebutuhan masyarakat akan pendidikan tinggi. Sutikno dan Malingreau dalam Ahmad (1997), menyebutkan bahwa penggunaan lahan adalah segala macam campur tangan manusia baik secara permanen ataupun secara siklus terhadap sekumpulan sumberdaya lahan dengan tujuan untuk memperoleh manfaat dari lahan, guna mencukupi kebutuhan hidupnya, baik berupa kebendaan maupun sprituil ataupun keduanya. Hal yang sama juga dijelaskan oleh Mangunsukardjo (Ahmad, 1997), bahwa penggunaan lahan merupakan bentuk penggunaan oleh manusia terhadap lahan, termasuk keadaan yang belum terpenuhi untuk mencukupi kebutuhan manusia.

Sementara Best dan Sinaga (Ahmad, 1997) memberikan pengertian penggunaan lahan ke dalam aspek keruangan dari semua aktivitas manusia atas lahannya dan secara adaptasi atau yang dapat diadaptasikan terhadap permukaan lahan untuk mencukupi kebutuhan manusia. Dalam hal ini penggunaan lahan sektor jasa pendidikan merupakan bentuk intervensi manusia terhadap lahan dan bukan bersifat alamiah yang bertujuan untuk meningkatkan produktivitas lahan yang berdampak pada meningkatnya nilai lahan.

Selanjutnya Jayadinata, merumuskan beberapa faktor yang menjadi penentu dalam pola penggunaan lahan yang salah satunya adalah faktor perilaku masyarakat (social behaviour) yang dipengaruhi oleh nilai-nilai sosial dan proses sosial yaitu : Sentralisasi, (terkumpulnya penduduk disebabkan oleh prasarana ekonomi) dan desentralisasi (Jayadinata, 1999). Dan dalam konteks penelitian ini keberadaan Kampus dapat menyebabkan sentralisasi atau pemusatan konsentrasi penduduk pada satu wilayah.

\subsubsection{Kampus Sebagai Penggerak Ekonomi}

Jasa pelayanan pendidikan skala regional bahkan nasional merupakan pasar potensial bagi kegiatan sektor ekonomi lain yang terkait dengannya. Peningkatan jumlah populasi sebagai akibat migrasi karena pendidikan berarti peningkatan akan permintaan barangbarang kebutuhan. Permintaan menurut Pappas dan Hirschey (1995) diartikan sebagai jumlah barang atau jasa yang rela dan mampu dibeli oleh para pelanggan selama periode tertentu berdasarkan sekelompok kondisi tertentu. Dengan kata lain, permintaan adalah jumlah total yang rela dan mampu dibeli oleh para langganan. Berkaitan dengan penelitian 
yang sedang dilakukan, maka barang-barang kebutuhan yang dimaksud cenderung merupakan konsumsi langsung bagi konsumen (mahasiswa, dosen dan karyawan) seperti makan, tempat tinggal, penggandaan dan percetakan, dan lain-lain. Namun apabila dikaitkan kembali dengan produk akhir jasa pendidikan berupa ilmu pengetahuan, maka yang dapat dikategorikan sebagai barang konsumsi tidak langsung adalah jasa kursus pendukung lainnya serta barang-barang berupa buku-buku referensi pendidikan.

Terkait dengan lokasi maka salah satu faktor yang turut mempengaruhi apakah suatu lokasi menarik untuk dikunjungi atau tidak adalah tingkat aksesibilitas. Tingkat aksesibilitas merupakan tingkat kemudahan di dalam mencapai dan menuju arah suatu lokasi di tinjau dari lokasi lain di sekitarnya (Tarigan, 2006). Menurut Tarigan tingkat aksesibilitas dipengaruhi oleh jarak, kondisi prasarana perhubungan, ketersediaan berbagai sarana penghubung termasuk frekuensinya dan tingkat keamanan serta kenyamanan untuk melalui jalur tersebut.

Wilayah sekitar kampus adalah "Pasar", karena dengan keberadaannya maka wilayah sekitarnya merupakan lokasi produksi dimana mahasiswa datang ke "pasar" untuk memenuhi kebutuhannya akan makan minum,tempat tinggal sementara (tempat kos), fotokopi, warnet, wartel, membeli segala kebutuhan kuliahnya dan lain- lain. Untuk memenuhi kebutuhan mahasiswa, masyarakat membuka usaha di sekitar Kampus agar mahasiswa dapat lebih mudah mendapatkan segala kebutuhannya, dengan aksesibilitas mudah, lebih efektif dan efisien.

\subsubsection{Karakteristik Dan Pola Tata Ruang}

Karakter fisik ruang kota perlu dikenali melalui elemen dasar lingkungan, bentuk ruang dan kualitas nilai suatu tempat. Pemahaman makna tentang nilai-nilai kultural, keunikan-keunikan, karakteristik suatu tempat akan membentuk suatu identity. Identitas akan memberikan "arti" sebagai pembentukan citra suatu tempat (place) (Lynch,1960; Schultz, 1980; Trancik, 1986).

Pada hakekatnya, karakter merupakan perwujudan watak yang membentuk citra adanya suatu identitas. Sedangkan pola tata ruang dipahami sebagai pola perwujudan struktur ruang dan pola ruang yang terjadi. Sehingga karakter dan pola tata ruang dapat diartikan sebagai perwujudan struktur dan pola peruntukan ruang baik untuk fungsi lindung dan budi daya yang membentuk citra dan identitas sebuah kawasan.

Sedangkan pola tata ruang dapat dikenali melalui elemen-elemen pembentuk ruang kota. Elemen ruang kota yang dapat mudah dikenali adalah elemen yang berkaitan dengan rancangan spatial lingkungan. Tidak hanya elemen-elemen fisik spesifik, tetapi juga elemenelemen penting lain yang penting bagi masyarakat. Karakter pola tata ruang dapat menjadi alat kajian yang digunakan untuk menjelaskan karakteristik ruang yang mempunyai ciri-ciri tertentu, sehingga dapat dibedakan atau dikelompokkan satu dengan lainnya.

Dengan demikian karakter dalam kajian ruang kota dapat menjelaskan sosok/ pola ruang mulai dari penggunaan lahan, hingga elemen ruang pendukung yang menjadi identitas dan penting yang dimiliki oleh ruang kota tersebut.

\subsection{Metode Penelitian}

Pendekatan yang digunakan dalam penelitian ini adalah penelitian kualitatif deskriptif. Pendekatan ini digunakan dengan tujuan untuk mendapatkan deskripsi suatu 
kejadian atau peristiwa dalam hal ini tentunya yang berkaitan dengan kejadian, peristiwa atapun bisa berupa fenomena pada kawasan sekitar kampus universitas Brawijaya.

Variabel-variabel yang akan diamati dalam penelitian ini adalah yang dapat memberikan makna ruang publik yang terkait dengan arsitektur (Car, 1992), yaitu: makna representasional atau obyektif, makna yang berkaitan dengan obyek, kejadian, ide, yang merupakan faktor yang berada di luar manusia.

Sedangkan penentuan sampel menggunakan pendekatan purposive sampling. Pendekatan purposive sampling yang dilakukan dengan cara mengambil subjek sebagai sampel bukan didasarkan atas strata, kedaerahan, secara acak, melainkan dipilih berdasarkan kriteria yang mengarah pada tujuan tertentu. Selain itu juga dalam pengumpulan data, dalam penelitian kualitatif-naturalistik, biasanya tidak menggunakan random sampling atau acakan serta tidak menggunakan populasi dan sampel yang banyak. (Nasution, 1988).

\section{Hasil dan Pembahasan}

\subsection{Struktur Ruang Kawasan}

Pada kawasan sekitar kampus UB struktur ruang kawasannya terlihat pada:

- Pusat-pusat permukiman, yang tersebar di sekitar kampus.

- Sistem sarana prasarana, yang melayani dan menunjang keberadaan pusat-pusat permukiman tersebut. Sistem tersebut meliputi sistem pelayanan, sistem jaringan transportasi, sistem listrik, sistem telekomunikasi, sistem air minum dan sistem infrastruktur lain.

Meski menempati lahan cukup besar ( $\pm 52 \mathrm{Ha}$ ), Kampus UB, nyatanya bukan salah satu unit lingkungan yang melayani kelurahan-kelurahan di sekitarnya. Hal dimungkinkan karena fungsinya sebagai fasilitas pendidikan tinggi dengan skala pelayanan yang jauh lebih besar.

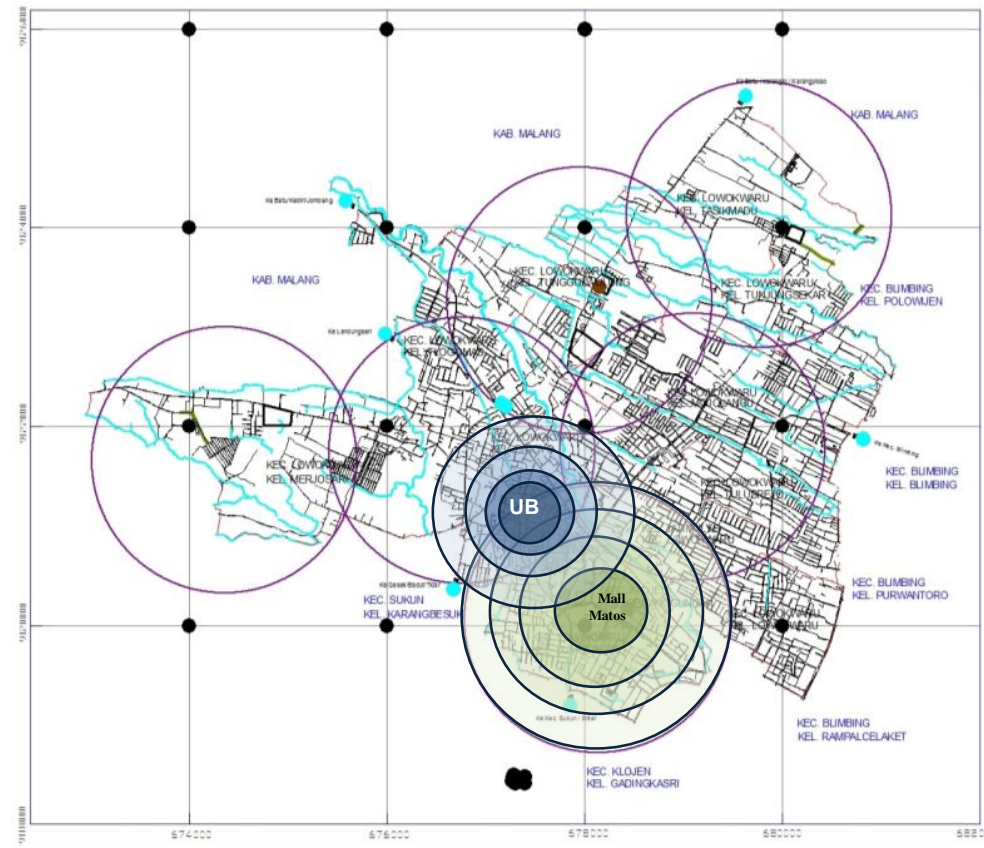

Gambar 1. Skala Pelayanan Kampus 


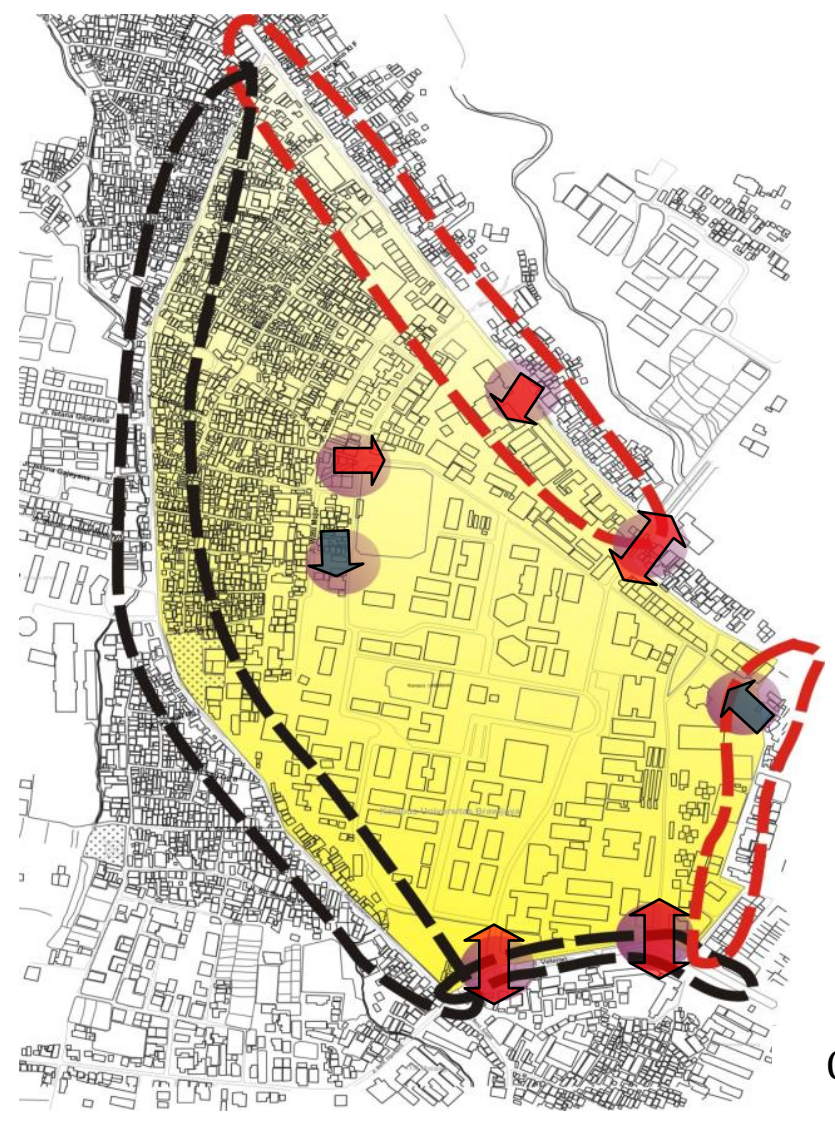

Pintu keluar masuk kendaraan

Area terdampak kepadatan lalu lintas

Gambar 2. Aksesibilitas Kampus dan Kepadatan

Kampus UB memiliki beberapa akses dari dan menuju kampus, antara lain:

- Pintu utama utara (jln. Veteran) sebagai pintu keluar masuk kampus bagi pengendara dari arah utara.

- Pintu utama selatan (jl.MT. Haryono) sebagai pintu keluar masuk kampus bagi pengendara dari arah selatan (jl. Soekarno-hatta).

- Pintu khusus utara (jl.Veteran) sebagai pintu keluar masuk menuju Samantha Krida, dan fasilitas publik lainnya.

- Pintu khusus selatan (jl. MT. Haryono dan Jl. Watu gong) sebagai pintu satu jalur (one way gate) baik masuk (MT.Haryono) dan keluar (jl. Watu Gong).

- Pintu pejalan kaki sebagai pintu khusus pejalan kaki dan roda 2 dari dan menuju kampus dari arah barat (jl. Watu mujur) dan dari arah timur (kampung keramik panjaitan)

\subsection{Pola Ruang Kawasan}

Berdasarkan Rencana Detail Tata Ruang Kota Malang Utara 2011-2031, Rencana pemanfaatan ruang kawasan sekitar kampus hingga tahun 2031 akan didominasi oleh peruntukan pengembangan permukiman seluas $\pm 417 \mathrm{Ha}$ dengan jumlah penambahan 23.166 unit rumah. Kawasan perdagangan dan jasa direncanakan akan berkembang di sepanjang jalan MT. Haryono, berupa toko modern, pusat PKL, dan pusat perbelanjaan berkarakter khusus, semacam elektronik, garment dan jasa. Untuk pengembangan kawasan pendidikan skala regional direncanakan di kawasan utara. 
Perkembangan pola pemanfaatan ruang sesungguhnya sudah terbaca sejak kampus UB berkembang kian cepat dengan penambahan mahasiswa 4-13\% pertahunnya. Selama 5 tahun terakhir, jumlah mahasiswa terdaftar (JMT) Universitas Brawijaya selalu mengalami kenaikan. Tahun 1999/2000 sebesar 13,54\%, tahun 2000/2001 sebesar 8,11\%, tahun 2002/2003 sebesar 4,13\%. Sedangkan pada tahun 2003/2004 terdaftar 32.602 orang atau mengalami kenaikan sebesar 3,19\%.

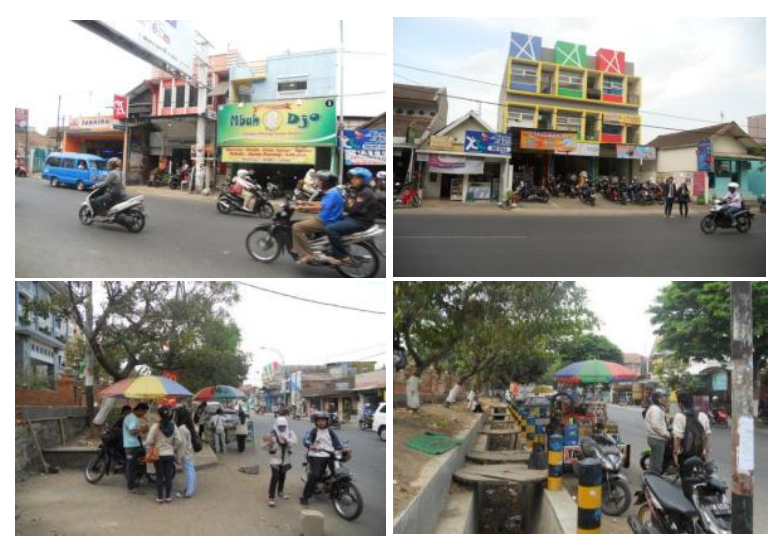

Gambar 3. Perdagangan dan jasa sepanjang Jl.MT Haryono

(Sumber: Analisis, 2013)

Peningkatan aktifitas perdagangan juga terjadi di kawasan permukiman padat penyangga kampus UB. Kawasan permukiman yang sebagian besar dihuni oleh mahasiswa ini mengalami perkembangan variasi perdagangan oleh masyarakat dari sebelumnya jasa kos-kosan menjadi perdagangan campuran.

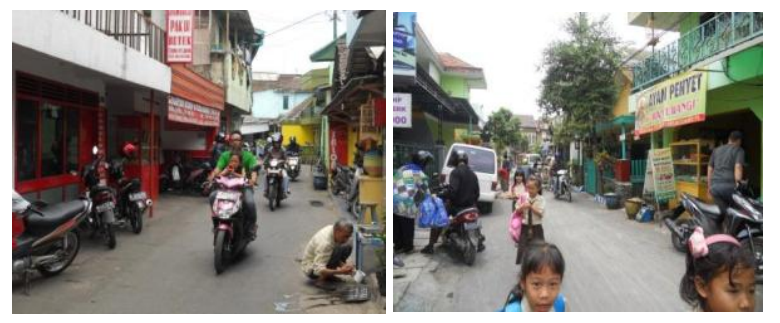

Gambar 4. Peningkatan aktifitas perdagangan di kawasan penyangga (buffer area).

(Sumber: Analisis, 2013)

Sirkulasi kendaraan di kawasan sekitar kampus di dominasi oleh kendaraan roda dua dan empat ukuran sedang. Lebar jalan yang relatif kecil tidak direncanakan untuk pemanfaatan parkir kendaraan. Sehingga parkir kendaraan lebih banyak memanfaatkan badan jalan (on street).

Ruang terbuka yang ada di kawasan sekitar kampus UB lebih banyak berupa jalan dan lahan terbuka non produktif. Perkembangan kebutuhan ruang menyebabkan masyarakat mengoptimalkan pemanfaatan lahan mereka hingga mengindahkan ruang terbuka sebagai daerah resapan air. Keberadaan ruang terbuka lebih banyak dimanfaatkan untuk area berdagang daripada untuk area hijau (RTH).

Akan tetapi taman RTH yang terletak di kawasan sekitar kampus dengan luas minimal kurang dari 0,25 Ha. (10\%) yaitu 0,17 Ha. Ruang urban yang terbentuk di sekitar Kampus UB memiliki grain halus/kecil karena pengguna ruang urban didominasi oleh mahasiswa yang memiliki keterbatasan pendapatan. 


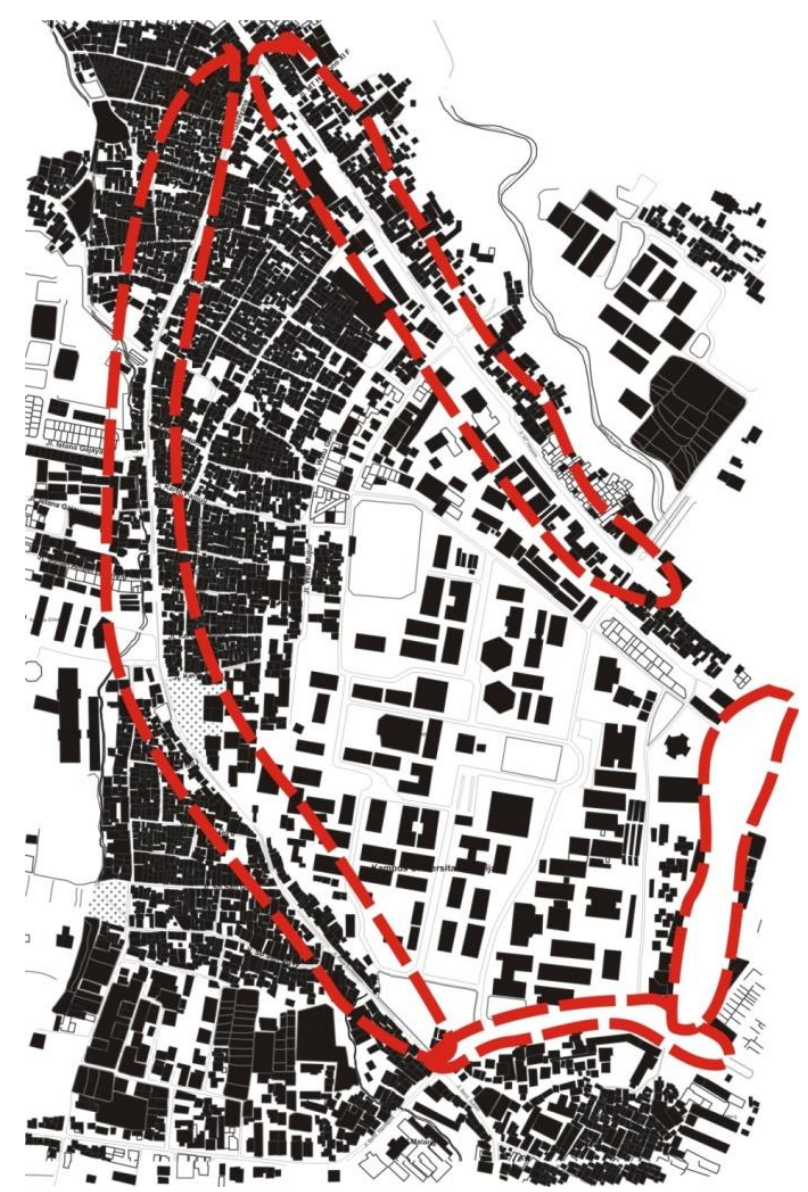

Gambar 5. Perbandingan Massa (solid) dan ruang terbuka (void) (Sumber: Analisis, 2013)

\subsection{Karakter Kawasan}

Karakter kawasan sekitar kampus salah satunya terbentuk oleh citra kawasan itu sendiri. Citra kawasan tertangkap oleh 5 elemen fisik kawasan yang ada. Keseluruhan elemen citra kawasan tersebut, antara lain: Gate, Path, Landmark, Nodes dan Edge. Mengingat kawasan sekitar kampus merupakan kawasan penyanggah kampus, maka tidak semua elemen fisik itu dapat ditemui dalam skala yang sesuai. Landmark lingkungan misalnya sulit ditemui pada kawasan tersebut.

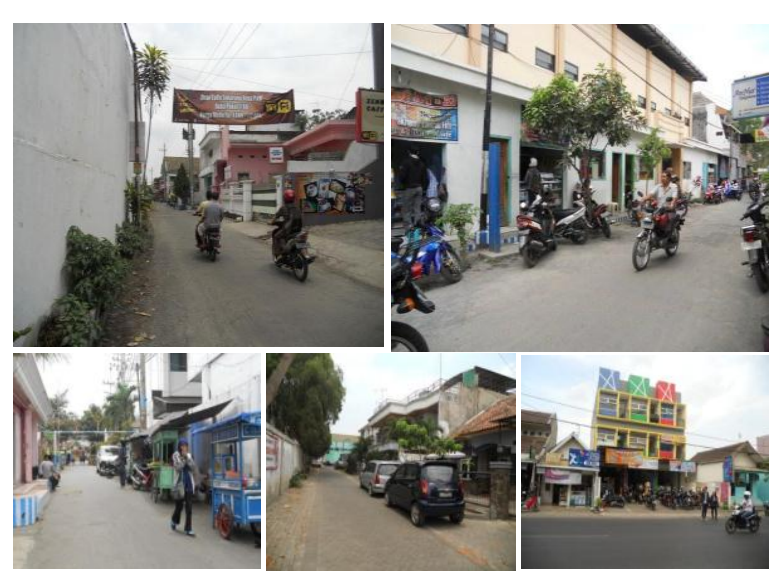

Gambar 6. Ki-ka: Path, Nodes, Gate, Edge dan Landmark

(Sumber: Analisis, 2013)

Jurnal RUAS, Volume 11 No 1, Juni 2013, ISSN 1693-3702 
Bentuk dan massa bangunan pada kawasan sekitar kampus terbentuk dalam dalam rasio ruang yang berbeda-beda.

- Bagian timur kampus: Rasio ruang yang terbentuk oleh lebar bangunan terhadap tinggi bangunan $(\mathrm{D} / \mathrm{H})$ adalah 1: 0,8 hingga $1: 1,6$

- Bagian barat kampus : D/H adalah 1: 0,8 hingga 1:2,6

- Bagian utara kampus: D/H adalah 1: 0,8 hingga 1: 1,6

- Bagian selatan kampus : D/H adalah 1: 0,8 hingga 1: 1,6

Sedangkan skala perkotaan yang terbentuk juga memiliki rasio yang berbeda-beda :

- Bagian timur kampus: memiliki skala yang manusiawi dengan dibuktikan oleh lebar jarak antar bangunan dan tinggi bangunan yang rata-rata memiliki rasio $1: 1,9$ atau 8m: $15 \mathrm{~m}$

- Bagian barat kampus : memiliki skala yang intim dengan dibuktikan oleh lebar jarak antar bangunan dan tinggi bangunan yang rata-rata memiliki rasio $1: 2,6$ atau $6 \mathrm{~m}$ : $15 \mathrm{~m}$

- Bagian utara kampus: memiliki skala yang manusiawi dengan dibuktikan oleh lebar jarak antar bangunan dan tinggi bangunan yang rata-rata memiliki rasio 1:1,9 atau 12m: $23 \mathrm{~m}$.

- Bagian selatan kampus: memiliki skala yang manusiawi dengan dibuktikan oleh lebar jarak antar bangunan dan tinggi bangunan yang rata-rata memiliki rasio 1:1,6 atau 12m: $18 \mathrm{~m}$.

Tanda (signs) selalu muncul di koridor utama sekitar kampus. Semakin mendekati pintu utama kampus, tanda dan media luar ruang yang ada makin meningkat intensitasnya. Keberadaan signs and symbols berupa tanda, baliho, spanduk, billboard, bahkan iklan bando menjadi bukti makin tingginya nilai ekonomis kawasan kampus. Keberadaannya menjadi hal yang mengkhawatirkan karena hampir menjadi sampah visual yang merusak pemandangan kota. Sign dan symbol harus hadir dengan pengendalian yang ketat, sehingga tidak menutup wajah bangunan (facade).

\section{Kesimpulan}

Berdasarkan hasil pembahasan tersebut diatas, dapat disimpulkan bahwa:

1. Keberadaan kampus Universitas Brawijaya, secara tata ruang berpengaruh pada:

- Pola tata ruang kawasan sekitarnya, dengan pemanfaatan lahan yang bervariasi sebagai dampak bangkitan kampus sebagai penggerak ekonomi kawasan sekitar.

- Karakter ruang kota di sekitar kampus mempunyai kesamaan di setiap sisinya. Karakter tersebut tidak terpengaruh oleh kondisi lebar jalan, dan status jalan yang dimilikinya.

- Terbentuknya ruang kota oleh deretan bangunan yang mengapit akses-aksesnya, tetapi tidak menciptakan karakter enclosure.

- Rasio ruang yang terbentuk oleh lebar bangunan terhadap tinggi bangunan $(D / H)$ adalah 1: 0,8 hingga 1: 2,6

- Ruang urban yang terbentuk di sekitar Kampus UB memiliki grain halus/kecil karena pengguna ruang urban didominasi oleh mahasiswa yang memiliki keterbatasan pendapatan.

- Skala perkotaan yang terbentuk masih memiliki skala yang manusiawi dengan dibuktikan oleh lebar jarak antar bangunan dan tinggi bangunan yang rata-rata memiliki rasio $1: 1,9$ : atau $12 \mathrm{~m}: 23 \mathrm{~m}$. 
2. Terbukanya aksesibilitas dari dan ke kampus Universitas Brawijaya berakibat pada berubahnya karakter ruang meso di sekitar kampus.

3. Perencanaan tata ruang kampus perlu mempertimbangkan dampak munculnya aktivitas bangkitan pada ruang kota sekitar kampus.

4. Ruang-ruang sosial, publik-privat yang ada di sekitar kampus perlu dipertahankan dengan menyediakan ruang-ruang transisi atau ruang ruang antara, sehingga beban ruang di sekitar kampus akan sedikit berkurang.

5. Pengembangan wilayah perlu dikelola secara terpadu dengan melibatkan pihak-pihak yang berkepentingan, terutama masyarakat sekitar, Kampus Universitas Brawijaya, dan Pemerintah Kota Malang.

\section{Daftar Pustaka}

Ahmad. 1997. Evaluasi Penggunaan Lahan Daerah Perbukitan dan Pengaruhnya terhadap Masalah Lingkungan Fisik di Kotamadya Ambon. Tesis. Yogyakarta: Program Pascasarjana UGM.

Carr, S., M. Francis, L.G. Rivlim, \& A.M. Stone. 1992. Public Space. Cambridge: Cambridge University Press.

Groat, Linda \& David Wang. 2002. Architectural Research Methods. New York: John Wiley \& Sons

Hariyani (2006), Pengaruh Kampus Terhadap Ruang Urban: Kasus Ruang Urban Pada Akses Masuk Kampus Universitas Gajah Mada. Tesis. Yogyakarta: Pasca Sarjana UGM

Jayadinata, Johara T. 1999. Tata Guna Tanah dalam Perencanaan Pedesaan Perkotaan dan Wilayah. Bandung: ITB Bandung.

Krier, Rob. 1979. Typological and Morphological Elements of The Concept of Urban Space. New York: Rizzoli.

Llewelyn-Davies. 2000. Urban Design Compendium. London: English Partnerships \& The Housing Corporation.

Nasution, 1988. Metodologi Penelitian Kualitatif. Bandung : PT. Remaja Rosdakarya.

Nurmandi, Achmad. 1999. Manajemen Perkotaan. Yogyakarta: Lingkaran Bangsa

Papas James dan Hirschey M, 1995. Ekonomi Manajerial, Edisi Keenam, Jilid I, Alih Bahasa : Daniel Wirajaya, Binarupa Aksara, Jakarta.

Richardson, H. 1972. Regional Economics. Location Theory, Urban Structure and Regional Change. Word University. London.

Rossi, Aldo, 1982. Architecture Of the City , London-England. The MIT Press.

Suharyanto (2007), Dampak Keberadaan IPB terhadapEkonomi Masyarakat Sekitar Kampus dan Kontribusinya terhadap Perekonomian Kabupaten Bogor, Tesis. Bogor: Program Pasca Sarjana IPB.

Santoso (2009), Karakteristik dan Persebaran Warung makan di sekitar Kampus Universitas Muhammadiyah Surakarta tahun 2009 : Studi kasus di Desa Pabelan dan Gonilan Kecamatan Kertasura Kabupaten Sukoharjo.Tesis. Surakarta: Program Pasca Sarjana UMS

Suripin, 2004. Sistem Drainase Perkotaan Berkelanjutan. Yogyakarta : Penerbit ANDI.

Tarigan, R. 2006. Perencanaan Pembangunan Wilayah (Edisi Revisi). Jakarta : PT.Bumi Aksara.

Tisdell, C. 1975. The Theory of Optimal City Sizes : Elementary Speculation about analysis and Policy. Urban Studies Journal: e-journal 